ESJ Social Sciences

\title{
Agricultural Output, Government Expenditure and Economic Growth in Nigeria: A Gregory-Hansen Cointegration Test with Structural Breaks
}

\author{
Ali Salisu \\ Adahama Ibrahim, Haladu \\ Department of Economics Bayero University, Kano, Nigeria
}

Doi:10.19044/esj.2021.v17n41p38

Submitted: 11 October 2021

Accepted: 08 December 2021

Published: 31 December 2021
Copyright 2021 Author(s)

Under Creative Commons BY-NC-ND

4.0 OPEN ACCESS

Cite As:

Salisu A. \& Haladu A.I. (2021). Agricultural Output, Government Expenditure and Economic Growth in Nigeria: A Gregory-Hansen Cointegration Test with Structural Breaks. European Scientific Journal, ESJ, 17 (41), 38. https://doi.org/10.19044/esj.2021.v17n41p38

\section{Abstract}

The agricultural sector at large plays a significant role in augmenting economic growth, serves as a source of income to the people, provides food to the teeming population, serves as a source of raw materials to the industries and provides foreign exchange to the country, etc. The current study investigates the short-run and long-run relationship among agricultural output, Government expenditure, and Economic growth in Nigeria using annual time series data from 1985 to 2019. The Zivot-Andrew unit root test indicates that gross domestic product, agricultural output, and exchange rate are stationary at first difference while government expenditure is stationary at level. The Gregory-Hansen test with structural break has confirmed the existence of a cointegration relationship among the variables employed. The Autoregressive Distributive Lag (ARDL) model with break indicates that, in the short-run agricultural output has a negative and statistically insignificant effect on real gross domestic product Nigeria, government expenditure has a positive and statistically significant effect on real gross domestic product in Nigeria, and the exchange rate has a positive and statistically significant effect on real gross domestic product in Nigeria. The break-point coefficient has positive and statistically significant. The long-run result shows that agricultural output has a positive effect on the real gross domestic product in Nigeria, government expenditure has a positive effect on real gross domestic product in Nigeria, 
and the exchange rate has positive effects on the real gross domestic product in Nigeria. The break coefficient shows positive and statistically significant. The study recommends that the Nigerian government should reduce the lending rate on agriculture and provide incentives to the farmers, this will encourage farmers to borrow and consequently, agricultural output will increase and the Nigerian government should increase its expenditure on agriculture to boost the sector and achieve higher economic growth.

Keywords: Agricultural output, Government expenditure, Economic growth

\section{Introduction}

The agricultural sector at large plays a significant role in augmenting economic growth, serves as a source of income to the people, provides food to the teeming population, serves as a source of raw materials to the industries and provides foreign exchange to the country, etc. A country's agricultural sector is expected to play a particularly important role in development performance. At the start of development, the agricultural sector typically constitutes the largest segment of economic activity in a developing country. Its contribution to employment is even larger than its share of output. Its performance determines the well-being of a large fraction of the population. It serves as a source of various resources that can be transferred to other fastergrowing sectors in the economy. It affects both economic well-being and equity, largely due to its share size (Udoh, 2011).

Agriculture has been defined as the production of food and livestock and the purposeful tendering of plants and animals, (Ahmed, 1993). He stated further that agriculture is the mainstay of many economies and it is fundamental to the socio-economic development of a nation because it is a major element and factor in national development. In the same view, Okolo (2004) described the agricultural sector as the most important sector of the Nigerian economy which holds a lot of potentials for the future economic development of the nation as it had done in the past. Notwithstanding the enviable position of the oil sector in the Nigerian economy over the past three decades, the agricultural sector is arguably the most important sector of the economy.

The role of the government in economic management is performed through the formulation and implementation of economic policy generally and fiscal policy in particular. As recognized by the new growth theory, public spending is an important factor for self-sustaining productivity gains and long-term growth. For instance, government expenditure can contribute to agricultural growth (and hence poverty alleviation), it has indirectly created rural non-farm jobs and increased wages. The real significance of government development lies in the fact that it imparts a greater amount of "trickle-down" 
benefits for the poor in the growth process than growth alone. While economic growth alone often reduces poverty only by increasing mean consumption, government expenditure on agriculture reduces poverty both by increasing the mean of consumption and improving the distribution of income (Fan, Zhang, and Zhang, 2000). Public spending (e.g., budget) is one of the most direct effective instruments used by governments to promote agricultural growth and poverty reduction. Public spending at the federal level and sub-national level follows a basic structure of recurrent spending and capital spending. This spending structure is characterized by different expenditure categories depending on the ministry, department or agency (Ihugba, Chinedu and Njoku, 2013).

The main objective of the paper is to investigate the short-run and longrun relationship between agricultural output, government expenditure, and economic growth in Nigeria and to offer policy recommendations based on the findings of the paper. The originality of this paper can be seen in two ways, firstly, it considered structural breaks of the series which none of the previous studies has taken into account. Secondly, in terms of the variable the current study used general government expenditure and agricultural output independently unlike previous studies that used government expenditure on agriculture as a single variable. The rest of the paper is organised as follows: literature review, methodology in which the objectives of the paper could be achieved, presentation and analysis of the empirical findings, and the final section concludes the paper.

\subsection{Overview of Agricultural Sector in Nigeria}

Before the discovery of the oil boom of the 1970s, the importance of agriculture to the economic development of Nigeria is enormous because agriculture was the main source of food and employment for a sizeable number of people. It also provides raw materials for industries, income for an individual and the government. For instance, in the 1960s, more than $80 \%$ of the rural population of Nigeria was engaged in one type of agricultural activity or the other and between 1963 and 1964, the sector contributed as much as $65 \%$ of the nation's Gross Domestic Product (GDP) (Muftau and Gafar, 2003; Aina, 2015). Total expenditure on agriculture, as percentages of overall expenditure, fluctuated from 4.57 percent in the 1986-1993 periods through an average of 4.51 percent per annum in 1994-1998 to 3.53 percent in 19992005 , reflecting the government's intensified efforts to reduce its size. Intense efforts at down-sizing also showed up in declines in the ratio to GDP of this component of public expenditure. As a percentage of GDP, it was 4.38 percent between 1986 and 1993, but thereafter, declined to remain at less than 1.0 percent from 1993 to 2005 (CBN, 2006). Capital expenditure on agriculture exhibited a similar trend. As a percentage of overall expenditure, it was 4.33 
percent per annum in 1986-1993 but declined to an annual average of 2.37 percent between 1999 and 2005. The total budgetary allocation for the agricultural sector for Central and State governments in 2016 was N196.3 billion representing 1.6 percent of their N12.3 trillion budget, while N254 billion was allocated representing 1.8 percent of their total budget of N13.5 trillion for the year 2017. From 1992-2016 the budget to the agricultural sector was less than 4\% except for 2001 with 5.69\%, $20054.44 \%$ and $20097.33 \%$ of the total budget (CBN, 2017).

As a ratio of GDP, capital expenditure in agriculture rose impressively from 1.45 in 1970-1979 to 4.32 percent in the years 1980 to 1985 . It, however, stayed at less than 1.0 percent between 1994 and 2005. Similarly, per capita expenditure on agriculture was N127.27 and N289.11, respectively, in 19941998 and 1999-2005. On the other hand, the agricultural sector of the economy did not attract significant foreign private investment. The distribution of cumulative foreign private capital flow by types of activity between 1970 and 2007 reveals that the agricultural sector lagged behind other major sectors (such as mining, manufacturing and services) in terms of share of total foreign private capital. The highest share of total foreign private capital recorded by the agricultural sector was 4.1 percent of total foreign capital flow in 1978 (CBN, 2008).

As a result of the low level of investment in the agricultural sector, output has fluctuated widely and productivity has also declined. On average, the sector grew at the rate of 11.4 per annum between 1960 and 2008. Further analysis of the performance of this sector indicates that the highest annual growth rates were recorded in the 1970s and 1980s, at 13.2 percent and 29.2 percent respectively. During the 1990s, the growth rate dropped to 3.4 percent. It rose at an annual growth rate of 6.9 percent during the period 2000-2005, and at 4.2 percent during the period 2005-2008.

Recently those roles seem to elude the country because of neglect resulting from the discovery of oil and the oil boom of the 1970s; the global economic crisis of the nation's terms of trade, and the continuous decline in government finance to the sector (Ijaiya and Ijaiya, 2003). Nigeria has diverse agro-ecological conditions that can support a variety of farming models. However, successive administrations over the years neglected agriculture and failed to diversify the economy away from overdependence on the capitalintensive oil sector. Nigeria, which was the largest net exporter of agricultural produce (groundnuts $42 \%$, palm oil $27 \%$, soya beans $28 \%$, and cocoa $18 \%$ in the 1960s, now spends over 1.2 trillion importing palm oil, canned beans and other food items (Akintola, 2011). The country has, however, the potentials to return to its previous position if adequate attention is given to agricultural growth. 
Policy through finance and the provision of rural infrastructure. This policy should aim at establishing a system of sustainable agricultural financing schemes and programmmes that could provide micro-credit facilities (Aina, 2015). Sadly, the small-holder farmers in Nigeria lack access to inputs to increase productivity, income and reduce poverty (Alpuerto et al, 2009). Despite numerous laudable agricultural programmes like the Agricultural support scheme of 2006, FADAMA Development Programmes, and Agricultural Credit Guarantee Scheme Fund among others, productivity has not improved (Oriola, 2009 and Ewetan et al, 2017).

\section{Empirical literature}

Several empirical studies have examined the impact of agricultural output on economic growth and government expenditure on economic growth in Nigeria and other countries in the world but the review of the literatures indicate inconsistency of the findings, example in the work of Chijioke and Amad (2020) examined the effects of government infrastructural expenditure on economic development in Nigeria using time series data. The study employed weighted least square and used gross domestic Product, spending on agriculture and natural resources, spending on transport and communication, spending on education and spending on healthcare delivery. Findings from the study revealed that governments spending on transport, communication, education, and health infrastructure have significant effects on economic growth; spending on agriculture and natural resources infrastructure recorded a significant inverse effect on economic growth in Nigeria. An element of fiscal illusion was observed in the government spending on agriculture and natural resources indicating that the government is not contributing as much as the private sector in spending on agriculture and natural resources infrastructure in Nigeria.

Abubakar, Yusuf, and Abdulmalik, (2020) examined the impact of state government expenditure on agricultural growth in Kogi state from 20002018 using time series data. The study employed Vector Autoregressive (VAR) Model and includes crop production, state government capital expenditure, and government recurrent expenditure. The result from VAR Model revealed that there is no significant relationship between government capital expenditure and agricultural growth in Kogi State. Similarly, the study also discovered that there is no significant relationship between recurrent expenditure and agricultural growth in Kogi State.

Idoko and Jatto (2018) examined the relationship between government expenditure on agriculture and economic growth in Nigeria from 1985- 2015. The study employed multiple regression analysis and Johansen co-integration test, variables used in the study include Real Gross Domestic Product, Government Expenditure on Agriculture, Capital Formation, 
Commercial Bank Credit to Agriculture, and Domestic Savings. The multiple regression results of the study revealed that there exists a positive and significant relationship between government expenditure on agriculture and economic growth in Nigeria. The insignificant nature of domestic savings estimates was implicative on the fact that the domestic savings in the country did not contribute to economic growth, and there is a need for it to be encouraged to prevent difficulties among small-scale farmers in accessing soft loans, and purchasing adequate and mechanized farming tools.

Diyoke, Yusuf and Demirbas (2017) investigated the impact of government expenditure on economic growth in some selected countries in Sub-Saharan Africa (SSA) using panel data. Generalized Methods of Moments (GMM) was adopted in the study and gross domestic product, export, investment, government expenditure, interest rate and oil export were used as variables. The result of the study shows a long-run relationship amongst the variables used in the study. Government expenditure, investment and oil exports were equally found to have impacted growth in the region. Although, government expenditure has not contributed positively to economic growth in the region as it was negatively signed.

Aina and Omojola (2017) examined the effect of government expenditure on agricultural sector performance in Nigeria between 1980 and 2013. The study employed Ordinary Least Squares and Error Correlation Mechanism (ECM) methods, variables used in the study are; Agricultural Production Output, Government Capital Expenditure on Agriculture and Government Recurrent Expenditure on Agriculture. The regression coefficient of interest rate impacted significantly on agricultural sector output and the coefficient of the exchange rate is rightly signed. The long-run dynamic result shows that the coefficient of government expenditure on agriculture variable is rightly signed as well as the check variables (interest and exchange rates). There exists a long-run relationship among the variables.

Al Fawwaz (2016) measured the impact of government expenditures on economic growth in Jordan during the period between 1980-2013 using time series data. The study employed the Ordinary Least Squares (OLS) regression technique and includes the gross domestic product, total government expenditure, capital government expenditure, and recurrent government expenditure as variables in the model. The results indicate that there is a positive impact for both total government expenditure and current government expenditure on economic growth. The study recommends that capital government expenditure should be directed mainly to current productive economic activities to stimulate activities in the economic sectors.

Abbas, Yuansheng Abdul and Luan (2016) examined the impact of government expenditure on the agricultural sector and economic growth in Pakistan over the period 1983-2011. Variables used in the study include gross 
domestic product, agriculture and government expenditure and employed the Johansen Co-integration test and Ordinary Least Squares (OLS) technique. The results of the Johansen Cointegration test showed that there exists a longrun relationship between government expenditure on agriculture, agricultural output, and economic growth in Pakistan. On the other hand, the empirical results of regression analysis revealed that agricultural output, government expenditure have a significant influence on the economic growth of Pakistan. It was also found out that the agriculture sector is still confronting some challenges like inadequate funding, underdeveloped infrastructure, poor agriculture marketing, and shortage of irrigation.

Ebong, Ogwumike, Udongwo and Ayodele (2016) assessed the impact of government capital expenditures on economic growth in Nigeria during 1970 and 2012. The study employed the Ordinary Least Squares (OLS) model. These results were positive and statistically significant at the 5\% level. The short-run impact of health capital expenditures on economic growth was 0.21 , while the long-run impact was 0.16 . These impacts were negative and insignificant. Expenditures on economic infrastructure had significant positive impacts on the growth of 0.28 in the short-run and 0.32 in the long run. Moreover, these expenditures do not crowd-out private investment. These results indicate that government expenditure on human capital development through the social services sector tended to promote economic growth unlike that on agriculture. Iheanacho (2016) examined the long and short-run relationship between public expenditure and economic growth in Nigeria from 1986-2014. The study used the Johansen cointegration and error correction approach and employed real gross domestic product per capita, recurrent expenditure, capital expenditure, and non-oil revenue as variables in the model. This study shows a negative and significant long-run relationship between economic growth (RGDPC) and recurrent expenditure coexists with a positive short-run relationship, highlighting the dual effects of recurrent expenditure on economic growth in Nigeria. For the capital expenditure, this study documents the negative and significant long-run effect of capital expenditure on economic growth in Nigeria.

Al Gifari (2016) examined the relationship between government expenditure and economic growth in Malaysia using panel data. The study employed a fixed-effect model and used GDP, trade openness, exchange rate, labour and capital as variables in the model. The result indicates that there is a negative correlation between government expenditure and economic growth in Malaysia for the last 45 years. Moreover, the classification of government expenditure indicates that only housing sector expenditure and development expenditure significantly contribute to lowering economic growth.

Ihugba, Chinedu and Njoku (2013) analyzed the relationship between Nigeria government expenditure on the agricultural sector and its contribution 
to economic growth, Engle-Granger two-step modeling (ECM) procedure to co-integration based on unrestricted Error Correction Model and Pairwise Granger Causality test was employed in the analysis. The findings of the study indicate that agricultural contribution to GDP (Gross Domestic Product) and total government expenditure on agriculture are cointegrated in this study. The speed of adjustment to equilibrium is $88 \%$ within a year when the variables wander away from their equilibrium values. Based on the result of the Granger causality, the paper concludes that a very weak causality exists between the two variables used in this study.

Mapfumo, Mushunje, and Chidoko (2012) investigated how government expenditure on agriculture has affected economic growth in Zimbabwe from 1980 to 2009. Variables used in the study are; Gross Domestic Product (GDP), Government agricultural Expenditure, government expenditure on extension, research and development, and credit assistance, and the model employed is Ordinary Least Squares (OLS). Results from the empirical analysis provide strong evidence indicating that agriculture is an engine of economic growth. The results from this study suggest that spending more on agricultural research and development can improve economic growth and ultimately reduce poverty. However, it can also be concluded that insufficient government agricultural expenditure on extension and credit assistance adversely affected economic growth in Zimbabwe, based on the results of the study. Udoh (2011) examined the relationship between public expenditure, private investment and agricultural output growth in Nigeria over the period 1970-2008. The study employed a bounds test and autoregressive distributed lag (ARDL) and used Agriculture, gross domestic product, Public expenditure, labour, and weather as variables in the model. The results of the error correction model show that an increase in public expenditure has a positive influence on the growth of agricultural output. However, foreign investment has an insignificant impact in the short run. Hence, it is recommended that policymakers should combine both private and public investment in a complementary manner to ensure that both short-run and longrun productivity of the agricultural sector is not undermined.

Iganiga and Unemhilin (2011) examined the effect of Federal government agricultural expenditure on the value of agricultural output using time series data. The study employed co-integration and the error correction model and includes total commercial credits to agriculture, consumer price index, annual average rainfall, population growth rate, food importation, and GDP growth rate. The study found that government capital expenditure was found to be positively related to agricultural output. With a one-year lag period, it shows that the impact of government expenditure on agriculture is not instantaneous. The policy import of the study is that investment in the agricultural sector is very imperative and this should be complemented with 
monitored credit facilities. River basins and irrigation facilities should be provided to have all-year-round agricultural product food importation should be banned to encourage local producers and population control should be intensified in the rural setting to avoid the Malthusian Prediction of pestilence and strife.

\section{Methodology}

\subsection{Model specification}

The paper examines the short-run and the long-run relationship between agricultural output, government expenditure, and economic growth in Nigeria from 1985 to 2019. The functional form of the model is presented as follows:

Where

$$
R G D P=F(A G R O U T, G O V E X P, E X R A T E)
$$

$R G D P_{t}=$ Real gross domestic product, is measured as a proxy to economic growth and is the dependent variable in the model.

$\beta_{1}$ AGROUT $_{t}=$ Agricultural output, is measured as total agricultural output percentage of GDP

$\beta_{2}$ GOVEXP $P_{t}=$ government expenditure, is measured as general government expenditure

$\beta_{3}$ EXRATE $_{t}=$ Exchange rate, is measured as the official exchange rate

$$
\varepsilon_{t}=\text { Error term }
$$

\subsection{The Gregory and Hansen}

The study used Gregory and Hansen test to measure the importance of structural breaks in the series, because ignoring the breaks in the series may lead to accepting the null hypothesis where it is supposed to be rejected.

The Gregory and Hansen (1996) technique extends Engle and Granger's (1987) procedure by allowing for a structural break in either the intercept or the intercept and the cointegrating coefficient at an unknown time. The proposed residual-based tests for the null hypothesis of no cointegration with a structural break against the alternative assumptions. They proposed the following four models to account for a single endogenous break:

Model 1: Level shift $(C)$

$$
y_{t}=\alpha_{0}+\alpha_{1} \Phi_{t \tau}+\beta_{1} x_{t}+\varepsilon_{t}, t=1, \ldots, n
$$

Where $\Phi_{t \tau}$ is a dummy variable such that $\Phi_{t \tau}=\left\{\begin{array}{l}1 \text { if } t>n \tau \\ 0 \text { if } t \leq n \tau\end{array}\right.$

And $\tau \in(0,1)$ denotes the relative timing of the break point. In model 1 , the structural break affects the intercept only; $\alpha_{0}$ is the intercept before the break and $\alpha_{1}$ is the change in intercept at the time of the break.

Model 2: Level shift with a trend $(C / T)$

$$
y_{t}=\alpha_{0}+\alpha_{1} \Phi_{t \tau}+\varphi_{1} t+\beta_{1} x_{t}+\varepsilon_{t}, t=1, \ldots, n
$$


In model 2 the break affects only the intercept however it contains a trend. Model 3: Regime shift where slope and intercept coefficients change (C/S)

$$
y_{t}=\alpha_{0}+\alpha_{1} \Phi_{t \tau}+\beta_{1} x_{t}+\beta_{2} x_{t} \Phi_{t \tau}+\varepsilon_{t}, t=1, \ldots, n
$$

In model three the structural breaks affect both the intercept and the slope coefficient. $\beta_{1}$ is the cointegrating slope coefficient before the shift and $\beta_{2}$ is the change in the cointegrating slope coefficient at the time of the break. Model 4: Regime shift where intercept, slope coefficients and trend change $(C / S / T)$

$$
y_{t}=\alpha_{0}+\alpha_{1} \Phi_{t \tau}+\varphi_{1} t+\varphi_{2} t \Phi_{t \tau}+\beta_{1} x_{t}+\beta_{2} x_{t} \Phi_{t \tau}+\varepsilon_{\mathrm{t}}
$$

For each of the above models, unit root tests are performed on the residual's series, $\varepsilon_{t}$, using $\mathrm{ADF}^{*}, z_{\alpha}$, and $z_{t}$ tests. Gregory and Hansen (1996) propose the following tests: Gregory and Hansen have tabulated critical values by modifying the Mackinnon (1991) procedure. The null hypothesis of Gregory and Hansen tests is that there is a unit root in the residuals and hence there is no cointegration while the alternative hypothesis is that there is no unit root in the residuals and hence there is cointegration with a single unknown break. The null hypothesis is rejected if the statistic $A D F^{*}$ is smaller than the corresponding critical values. The test statistics can also be measured using the Philip test statistics that are denoted as $Z^{*}{ }_{\alpha}$ and $Z_{t}^{*}$. The above four Gregory and Hansen cointegration models can be extended to occupy more than one explanatory variable.

\subsection{Stability Test}

Having estimated the error correction model for Nigeria's economic growth, we then proceed to investigate the stability of the model. This is done based on the CUSUM and CUSUMSQ tests of Brown et al (1975).

The CUSUM test statistic is given as:

$$
W=\sum_{j=k+1}^{t} \frac{\hat{e}_{j}}{\hat{\sigma}_{\epsilon}}
$$

Where $\hat{e}_{j}$ is the recursive residual and $\hat{\sigma}_{\epsilon}$ is the standard deviation of the recursive residual, defined as

$$
\hat{\sigma}_{\epsilon}=\sqrt{\left(\frac{1}{T-K} \sum_{t=1}^{T}\left(\epsilon_{t}-\widehat{\epsilon}\right)^{2}\right)} .
$$

For robustness, the cumulative sum of squares test is also applied.

$$
\boldsymbol{S}_{\boldsymbol{t}}=\left(\sum_{r=k+1}^{t} w_{r}^{2}\right) /\left(\sum_{r=k+1}^{t} w_{r}^{2}\right)
$$

Where $w_{t}$ is the recursive residuals computed for $t=k+1, \ldots, T$. The expected value of under the hypothesis of parameter constancy is:

$$
E\left(S_{t}\right)=(t-k)(T-k) \text {. }
$$


Which goes from zero at $t=k$, to unity at $t=T$. The significance of the departure of $S$ from its expected value is assessed by reference to a pair of parallel straight lines around the expected value.

The G-Hansen model is specified as

$$
\begin{aligned}
& R G D P_{t}=\alpha_{0}+\alpha_{1} \Phi_{t \tau}+\beta_{1} \text { AGROUT }_{t}+\beta_{2} \text { GOVEXP }_{t}+\beta_{3} \text { EXRATE }_{t}+ \\
& \varepsilon_{t} \\
& R G D P_{t}=\alpha_{0}+\alpha_{1} \Phi_{t \tau}+\varphi_{1} t+\beta_{1} \text { AGROUT }_{t}+\beta_{2} \text { GOVEXP }_{t}+ \\
& \beta_{3} \text { EXRATE }_{t}+\varepsilon_{t} \ldots . .(3.11)
\end{aligned}
$$

$R G D P_{t} \alpha_{0}+\alpha_{1} \Phi_{t \tau}+\beta_{1}$ AGROUT $_{t}+\beta_{11}$ AGROUT $_{t} \Phi_{t \tau}+\beta_{2}$ GOVEXP $_{t}+$ $\beta_{22}$ GOVEXP $_{t} \Phi_{t \tau}+\beta_{3}$ EXRATE $_{t}+\beta_{33}$ EXRATE $_{t} \Phi_{t \tau}+\varepsilon_{t}$

$$
\begin{array}{r}
R G D P_{t} \alpha_{0}+\alpha_{1} \Phi_{t \tau}+\varphi_{1} t+\varphi_{2} t \Phi_{t \tau}+\beta_{1} \text { AGROUT }_{t}+\beta_{11} \text { AGROUT }_{t} \Phi_{t \tau}+ \\
\beta_{2} \text { GOVEXP }_{t}+\beta_{22} \text { GOVEXP }_{t} \Phi_{t \tau}+\beta_{3} \text { EXRATE }_{t}+\beta_{33} \text { EXRATE }_{t} \Phi_{t \tau}+
\end{array}
$$

\subsection{ARDL Model}

The study employed Auto Regressive Distributive Lag (ARDL) model to examine the short-run and long-run relationship among agricultural output, government expenditure, and economic growth in Nigeria.

The Auto-Regressive Distributive Lag (ARDL) model is specified as

$$
\begin{array}{r}
\Delta R G D P_{t}=\mu+\sum_{i=1}^{n-1} a_{i} \Delta R G D P_{t-1}+\sum_{i=0}^{m-1} \beta_{i} \Delta \text { AGROUT }_{t-i}+ \\
\sum_{i=0}^{m-1} Y_{i} \Delta \text { GOVEXP }_{t-i}+\sum_{i=0}^{m-1} u_{i} \Delta \text { EXRATE }_{t-i}+ \\
\sum_{i=0}^{m-1} \delta_{i} \Delta \text { DUMMY } Y_{t-i}-\pi \hat{e}_{t-1}+\varepsilon_{t} \ldots \ldots(3.14)
\end{array}
$$

If $\pi=1$ then $100 \%$ of the adjustment takes place within a single period (instantaneous/full adjustment). If $\pi=0$ then there is no adjustment. Thus, any other value is interpreted accordingly; a value of $\pi$ closer to 1 implies quick adjustment, and a value closer to 0 implies slow adjustment. To select the most fitted model lag length are chosen automatically by Akaike Information Criterion (AIC).

The null and alternative hypothesis for bound test concerning the cointegration test is:

Ho: $a_{i}=\beta_{i}=\Upsilon 1=u_{i}=v_{i}=\omega_{i}=0$ (No long-run relationship).

$\mathrm{H} 1: a_{i} \neq \beta_{i} \neq \Upsilon 1 \neq u_{i} \neq v_{i} \neq \omega_{i} \neq 0$ (there is long-run relationship). 


\section{Empirical Results and Discussion}

\subsection{Descriptive statistics}

Table 4.1 Descriptive statistics

\begin{tabular}{|c|c|c|c|c|}
\hline Statistics & LRGDP & LAG & LGOVEXP & LEXRATE \\
\hline Mean & 11.10368 & 1.370589 & 0.463422 & 1.045153 \\
\hline Median & 10.97948 & 1.368689 & 0.327040 & 1.040582 \\
\hline Std. Dev. & 0.429461 & 0.067048 & 0.349668 & 0.016752 \\
\hline Skewness & 0.181718 & 0.850690 & 0.117599 & 0.161013 \\
\hline Kurtosis & 1.390506 & 3.992772 & 1.461127 & 1.393292 \\
\hline Jarque-Bera & 3.970397 & 5.658759 & 3.534195 & 3.915931 \\
\hline Probability & 0.137353 & 0.059049 & 0.170828 & 0.141145 \\
\hline Observations & 35 & 35 & 35 & 35 \\
\hline
\end{tabular}

Source: Computation using E-views 10.

Table 4.1 shows the result of descriptive statistics of the study, it indicates that the standard deviations of the variables employed are not far away from their means except real gross domestic product (0.429461). The skewness of the distribution shows positive values and less than one of all the variables employed, which implies that these variables are skewed to the right and are normally distributed. For kurtosis all the variables are normally distributed because are less than 3 or equal to 3 , this means that these variables are normally distributed. The Jarque-Bera test for normality is also estimated. The result indicates the rejection of the null hypothesis of all the variables employed because their p-value is greater than 5\% which means that are normally distributed.

\subsection{Unit Root Test}

\subsubsection{Augmented Dickey-Fuller (ADF), Phillips Perron (PP)}

The study estimated the unit root test of both Augment Dickey-Fuller and Phillips Perron to identify the order of integration of the variables under study.

Table 4.2 Augmented Dickey-Fuller (ADF), Phillips Perron (PP)

\begin{tabular}{|c|c|c|c|c|}
\hline & \multicolumn{3}{|l|}{ Test at level } & $\begin{array}{c}\text { Test at first } \\
\text { difference }\end{array}$ \\
\hline Variables & ADF test & PP test & ADF test & PP test \\
\hline LRGDP & -2.602396 & -2.585308 & -4.763321 & -4.760462 \\
\hline LAG & -1.747286 & -2.220994 & -6.784276 & -7.132749 \\
\hline LGOVEXP & -2.260509 & -2.299674 & -5.772793 & -5.786270 \\
\hline LEXRATE & -2.620702 & -2.605862 & -4.833686 & -4.829056 \\
\hline
\end{tabular}

Source: Computation using E-views 10.

Table 4.2 presents the result of Augment Dickey-Fuller and Phillips Perron unit root tests, the tests show that all the variables under ADF and PP tests are stationary at first difference i.e. are I(1) process. 


\subsubsection{Zivot and Andrew Unit Root Test}

Table 4.3 Zivot-Andrew Unit Root Test

\begin{tabular}{|c|c|c|c|c|}
\hline & \multicolumn{3}{|c|}{ Level } & First difference \\
\hline Variables & Statistics & Break point & Statistics & Break point \\
\hline LRGDP & -2.645311 & 2014 & -6.149535 & 1994 \\
\hline LAG & -4.610839 & 2002 & -5.428843 & 2005 \\
\hline LGOVEXP & -6.065023 & 2004 & - & - \\
\hline LEXRATE & -2.705277 & 2014 & -6.324122 & 1994 \\
\hline
\end{tabular}

Source: Computation using E-views 10.

Table 4.3 indicates inconsistent results with the traditional unit root test shown in table 4.2. Evidence from the Zivot-Andrew unit root test indicates that real gross domestic product, agricultural output and exchange rate are stationary at the first difference, the break dates are 1994, 2005 and 1994 while government expenditure is stationary at the level and the break date is 2004. Conclusively, considering breaks in the series is very important, because it may lead to accepting the Null hypothesis of the unit root test when it should have been rejected.

\subsection{Gregory-Hansen cointegration test}

\begin{tabular}{|c|c|c|c|c|c|c|}
\hline Models & ADF * & $\begin{array}{c}\text { Break } \\
\text { point }\end{array}$ & $\mathbf{Z t}^{*}$ & $\begin{array}{c}\text { Break } \\
\text { point }\end{array}$ & $\mathbf{Z} \boldsymbol{\alpha}^{*}$ & $\begin{array}{c}\text { Break } \\
\text { point }\end{array}$ \\
\hline $\bar{C}$ & -5.88 & 2007 & -5.92 & 2011 & -35.46 & 2011 \\
\hline $\mathrm{C} / \mathrm{T}$ & -5.23 & 2011 & -5.31 & 2011 & -30.87 & 2011 \\
\hline $\mathrm{C} / \mathrm{S}$ & -6.95 & 2005 & -6.74 & 2010 & -43.22 & 2010 \\
\hline $\mathrm{C} / \mathrm{S} / \mathrm{T}$ & -6.85 & 2010 & -6.96 & 2010 & -40.59 & 2010 \\
\hline
\end{tabular}

Source: Computed using Stata 14.

The result from table 4.4, indicates a cointegration among the variables employed, sticking to ADF statistics because the lower the value the better model and is higher than the critical value at 5\%, Taking the break date to be 2011. Therefore, we can reject the null hypothesis of no cointegration. The test does suggest that considering a structural break in the cointegration vector is important and needs to be taken care of in the specification of real gross domestic product functions in Nigeria.

\subsection{Results of Autoregressive Distributed Lag (ARDL) model}

As a result of unit root and bound tests conducted in the study which suggests the use of the ARDL model. The appropriate model (number of lags) is selected automatically using Akaike Information Criterion (AIC) which is seen as a more robust model. Below, both short-run and long-run parameters of the model are presented. 


\subsubsection{Short-run Relationship}

Below the result of short-run parameters of the ARDL model is presented. AIC suggests a $(3,4,3,3,3)$ model after testing for up to 2500 different models.

Table 4.5 Short-run parameters of the ARDL model

\begin{tabular}{|c|c|c|c|c|}
\hline Variables & Coefficient & Std. Error & t-Statistic & Prob. \\
\hline$\Delta(\operatorname{LGDP}(-1))$ & 0.348150 & 0.161262 & 2.158916 & 0.0562 \\
\hline$\Delta(\operatorname{LGDP}(-2))$ & 0.610325 & 0.153792 & 3.968500 & 0.0026 \\
\hline$\Delta(\mathrm{LAG})$ & -0.005511 & 0.007629 & -0.722323 & 0.4866 \\
\hline$\Delta(\mathrm{LAG}(-1))$ & 0.018910 & 0.008810 & 2.146313 & 0.0574 \\
\hline$\Delta(\mathrm{LAG}(-2))$ & -0.019247 & 0.008797 & -2.187819 & 0.0535 \\
\hline$\Delta(\mathrm{LAG}(-3))$ & 0.015497 & 0.009580 & 1.617593 & 0.1368 \\
\hline$\Delta($ GOVEXP $)$ & 0.002546 & 0.000412 & 6.183764 & 0.0001 \\
\hline$\Delta(\operatorname{GOVEXP}(-1))$ & -0.001872 & 0.000517 & -3.620123 & 0.0047 \\
\hline$\Delta($ GOVEXP(-2)) & -0.000548 & 0.000326 & -1.680921 & 0.1237 \\
\hline$\Delta($ LEXRATE $)$ & 0.472502 & 0.106000 & 233.2539 & 0.0000 \\
\hline$\Delta($ LEXRATE $(-1))$ & -0.567338 & 4.003643 & -2.139885 & 0.0580 \\
\hline$\Delta($ LEXRATE $(-2))$ & -0.392924 & 3.813816 & -3.914516 & 0.0029 \\
\hline$\Delta($ DUMMY $)$ & 0.015937 & 0.002696 & 5.911306 & 0.0001 \\
\hline$\Delta($ DUMMY $(-1))$ & -0.023941 & 0.004388 & -5.455761 & 0.0003 \\
\hline$\Delta($ DUMMY $(-2))$ & -0.010683 & 0.002969 & -3.597893 & 0.0049 \\
\hline & & & & \\
\hline & & & & \\
\hline & & & & \\
\hline & & & & \\
\hline & & & & \\
\hline & & & & \\
\hline Prob(F-statistic) & 0.000000 & & & \\
\hline R-squared & 0.999790 & & & \\
\hline Adjusted R-squared & 0.999579 & & & \\
\hline Serial correlation & 0.0117 & & & \\
\hline Heteroscedastics & 0.2558 & & & \\
\hline Normality & 0.747430 & & & \\
\hline Ramsey test & 0.0000 & & & \\
\hline
\end{tabular}

Source: Computation using E-views 10.

The result from table 4.4 indicates positive and significant autoregressive of dependent variable i.e. GDP at lag 1 and lag 2 in the shortrun, it shows that real gross domestic product depends largely on itself in the short run. The agricultural output itself depicts a negative and statistically insignificant effect on the real gross domestic product Nigeria in the short-run, at lag 1 and 3 indicate a positive while at lag 2 shows a negative effect. Government expenditure itself indicates a positive and statistically significant effect on the real gross domestic product in Nigeria in the short-run, at lag 1 shows negative effect on real gross domestic product in Nigeria. The exchange 
rate shows a positive and statistically significant effect on real gross domestic product in Nigeria in the short run, at lag 1 and 2 show a negative and statistically significant effect on the real gross domestic product in Nigeria. The break-point coefficient itself indicates a positive and statistically significant, this means that the break-point has a significant impact in this model, at lag 1 and 2 indicate negative but statistically significant. The p-value of F-statistics indicates (0.000000), which means that agricultural output, government expenditure, and exchange rate have a $100 \%$ significant influence on the real gross domestic product in Nigeria.

The R-squared and its adjusted value are very high 0.999790 , this implies that $99 \%$ change in real gross domestic product is explained by agricultural output, government expenditure and exchange rate in Nigeria. The model passed post estimation tests such as Heteroscedasticity and normality test, as their probability values are greater than $5 \%$.

\subsubsection{Long-run and Error Correction Result}

As a result of the bound test, which confirms the existence of a longrun relationship among the variables of interest.

Table 4.6 ARDL Cointegration and Long-run form Results

\begin{tabular}{|c|r|r|r|c|}
\hline Variables & Coefficient & Std. Error & t-Statistic & Prob. \\
\hline LAG & 0.005966 & 0.009393 & 0.635155 & 0.5396 \\
\hline GOVEXP & 0.003205 & 0.000354 & 9.044047 & 0.0000 \\
\hline LEXRATE & 0.472289 & 0.084977 & 290.9346 & 0.0000 \\
\hline DUMMY & 0.022422 & 0.002444 & 9.173767 & 0.0000 \\
\hline CointEq(-1) & -0.798100 & 0.262932 & -3.035385 & 0.0000 \\
\hline
\end{tabular}

Source: Computation using E-views 10.

The result from table 4.5 indicates that agricultural output has a positive but statistically insignificant impact on gross domestic product in Nigeria in the long run, this is in line with economic apriori expectation which confirmed the positive impact of agricultural output on the real gross domestic product in Nigeria. The positive finding is similar to the findings of Abbas et al (2016) and Mapfumo et al (2012). Furthermore, Government expenditure indicates a positive and statistically significant impact on the real gross domestic product in Nigeria in the long run, this implies that one unit increase in government expenditure will bring about a $0.003 \%$ increase in the gross domestic product in Nigeria, this in line with apriori expectation which proved that government expenditure impacted positively on the real gross domestic product in Nigeria. The positive finding is similar to the findings of Idoko et al, (2018), Abbas et al (2016), and Al Fawwaz (2016) while countering the finding of Al Gifari (2016). The exchange rate shows a positive and statistically significant effect on the real gross domestic product in Nigeria in the long run, by implication N1 increase in the exchange rate will cause $0.47 \%$ 
increases in the real gross domestic product in Nigeria. Furthermore, the break coefficient shows a positive and statistically significant, by implication considering the break in the model is very significant.

The error correction term (ECT) meets all the theoretical and statistical requirements both in the sign and size. The ECT coefficient is -0.798100 and significant at $5 \%$, which indicates that $79.81 \%$ of the disequilibrium due to the shock in the previous years is adjusted back to the long-run equilibrium in the current year.

\subsubsection{Stability}

A stability test of the model is employed to ensure the data generating process is compatible with the estimated coefficient of the model.

Figure 4.1 Cusum Pot Recursive Residual of ARDL model

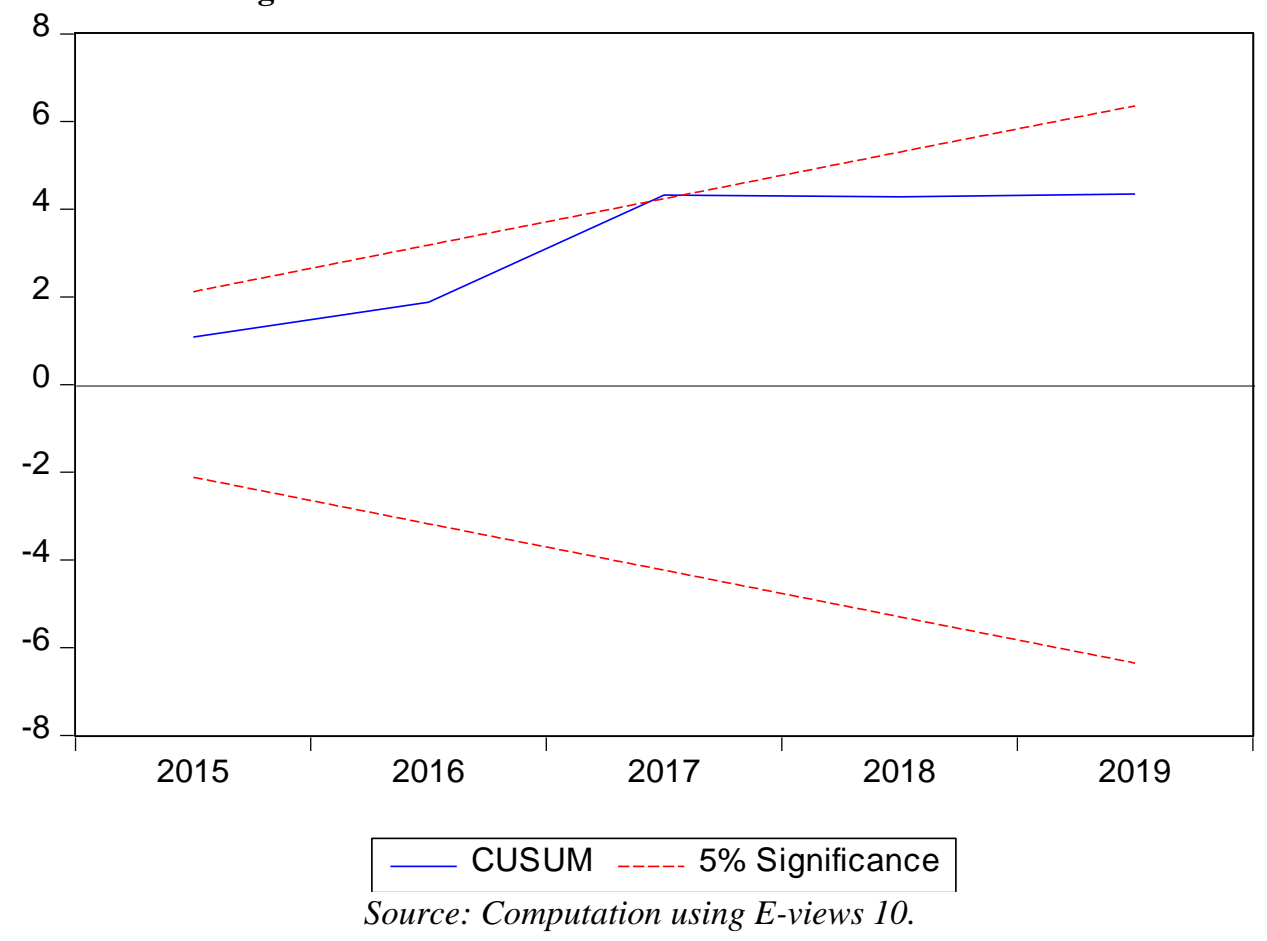

From Figure 4.1, the CUSUM plot is within a 5\% level of significance, this means that the model is stable. This shows that there is no chance of having spurious regression. 
Figure 4.2 Cusum Square Plot Recursive Residual of ARDL Model

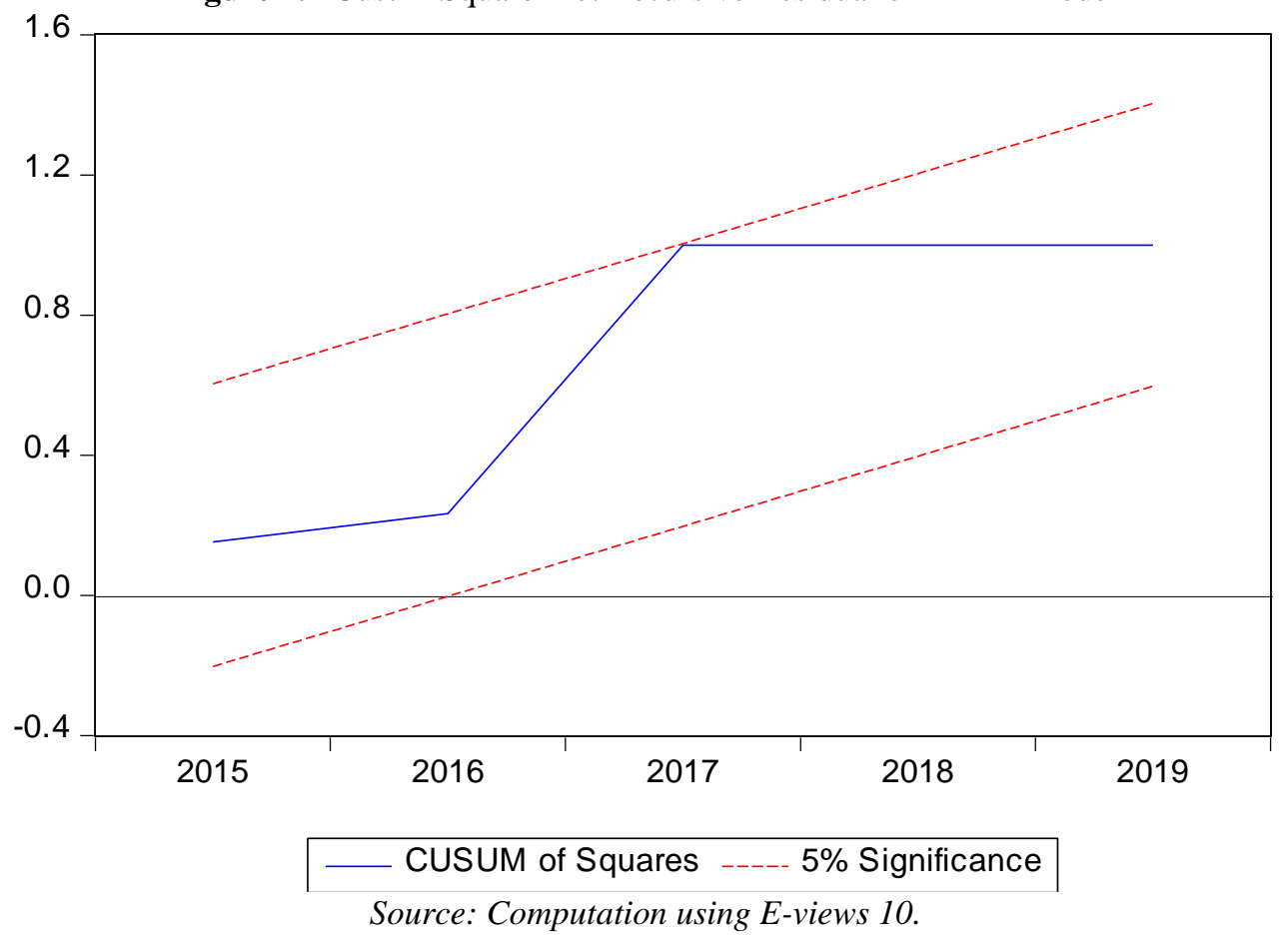

From Figure 4.2, the CUSUM plot is within a 5\% level of significance, this means that the model is stable. This shows that there is no chance of having spurious regression.

\section{Conclusion and Recommendation}

The paper investigates the relationship between agricultural output, government expenditure, and economic growth in Nigeria using annual data from 1985 to 2019. The Auto-Regressive Distributive lag (ARDL) model with structural break is used in the analysis. The Gregory-Hansen cointegration with break has confirmed the existence of cointegration among the variables employed. The long-run result indicates that agricultural output has a positive but statistically insignificant effect on the real gross domestic product in Nigeria, government expenditure has a positive and statistically significant effect on the real gross domestic product in Nigeria, and the exchange rate has a positive and statistically significant effect on the real gross domestic product in Nigeria. The break coefficient shows a positive and statistically significant. The error correction term (ECT) indicates that $79.81 \%$ of the disequilibrium due to the shock in the previous years is adjusted back to the long-run equilibrium in the current year. Conclusively, the paper recommends that the Nigerian government should reduce the lending rate on agriculture and provide incentives to farmers, by so doing farmers will be encouraged to 
borrow and consequently agricultural output will increase via the multiplier effects. Government should provide infrastructural facilities such as good roads, pipe-borne water, and electricity to increase agricultural output and finally higher economic growth could be achieved. The Nigerian government should increase its expenditure on agriculture to boost the sector and achieve higher economic growth.

\section{References:}

1. Abbas A. C., Yuansheng J., Abdul R. \& Luan J. (2016) Impact of Government Expenditure on Agricultural Sector and Economic Growth in Pakistan. International Journal of Advanced Biotechnology and Research (IJBR), 7(3), 1046-1053, http://www.bipublication.com.

2. Abubakar, F., Yusuf, H. A. \& Abdulmalik, T. A. (2020) Impact of Government Expenditure on Agricultural Growth in Nigeria: Empirical evidence from Kogi State. International Journal of Intellectual Discourse (IJID), 3(1), $666-680$.

3. Ahmed, Y. O. (1993). "Bank of the North Pamphlets on Agricultural Financing. Various circulars and Policy Guidelines on Agricultural Financing in Bank of the North Limited." A Paper delivered at Seminars at Bank of the North Human Resources and Development Centre by (Agric. Officer, Bank of the North Limited).

4. Aina, G. O. \& Omojola, J.T. (2017) Assessment of the Effect of Government Expenditure on Agricultural Output in Nigeria. International Journal of Innovative Agriculture \& Biology Research 5(4), 1-7, www.seahipaj.org.

5. Aina, G.O. (2015). Government Spending and Agricultural Output in Nigeria (1980-2013). An unpublished M.Sc. Thesis. Department of Economics, University of Port Harcourt, Nigeria.

6. Akintola, A. (2011). Nigeria; A New Perspective Being. A paper presented by the Minister of Agriculture on the Neglect of Agricultural sector, 18th September, 2011. Kano, Nigeria.

7. Al Fawwaz, T. M. (2016) The Impact of Government Expenditures on Economic Growth in Jordan. International Business Research; 9(1), $99-105$.

8. Al Gifari, H. (2016) The effects of government expenditure on economic growth: the case of Malaysia. INCEIF, Global University of Islamic Finance Munich Personal RePEc Archive (MPRA) No. 71254, $1-15$.

9. Alpuerto, V.; Xstan, S. \& Nwafor, M. (2009). Agricultural Investment for Growth and Poverty Reduction in Nigeria. International Food Policy Research, Abuja. 
10. Asteriou, D. and Hall, S. (2007). Applied Econometrics. A Modern Approach Using Eviews and Microfit Revised Edition, New York US Palgrave Macmillan.

11. Brown, R. L., Durbin, J. \& Evans, J. M. (1975). Techniques for Testing the Constancy of Regression Relationships Over Time, Journal of the Royal Statistical Society, Series B (37), 149-192.

12. CBN (2017). Statistical Bulletin_Real Sector_Final. Retrieved from statistics.cbn.gov.ng/cbn-onlinestats.

13. Chijioke,A. K. \& Amad, A. I. (2020) Government Expenditure on Infrastructure as a Driver for Economic Growth in Nigeria. Journal of International Business Research and Marketing 5(2), 20-26, DOI: 10.18775/jibrm.1849-8558.2015.52.3004.

14. Diyoke, K. O. Yusuf A. \& Demirbas, E. (2017) Government Expenditure and Economic Growth in Lower Middle Income Countries in Sub-Saharan Africa: An Empirical Investigation. Asian Journal of Economics, Business and Accounting, Vol. 5(4): 1-11.

15. Ebong, F.,Ogwumike, F., Udongwo, U. \& Ayodele, O. (2016) Impact of Government Expenditure on Economic Growth in Nigeria: A Disaggregated Analysis. Asian Journal of Economics and Empirical Research, 3(1), 113-121, DOI: 10.20448/journal.501/2016.3.1/501.1.113.121.

16. Engle, R. F. \& C. Granger (1987). Cointegration and Error Correction, Representation, Estimation and Testing, Econometrica, 55: 251-276.

17. Ewetan, O., Fakile, A., Urhie, E. \& Ountan, E. (2017). Agricultural output and Economic Growth in Nigeria. Journal of African Research in Business and Technology. 2017.

18. Fan, S. Zhang, L. \& Zhang, X. (2000) Growth and poverty in rural China: the role of public investment. Environment and Technology Division Discussion paper 66. Washington DC. IFPRI.

19. Gregory, A. \& Hansen, B. (1996). Residual-based Tests for Cointegration in Models with Regime Shifts. Journal of Econometrics 10: 321-335.

20. Gregory, A. W., Nason, J. M. \& Watt, D. (1996). Testing for Structural Breaks in Cointegrated Relationships', Journal of Econometrics, 71, 321-42.

21. Idoko, C. U \& Jatto, S. M. (2018) Government expenditure on agriculture and economic growth in Nigeria. International Journal of Academic Research and Reflection, 6(4), 24 - 39.

22. Iganiga, B.O. \& Unemhilin, D. O. (2011) The Impact of Federal Government Agricultural Expenditure on Agricultural Output in Nigeria. Journal of Economics, 2(2), 81-88, DOI:10.1080/09765239.2011.11884939. 
23. Iheanacho E. (2016) The Contribution of Government Expenditure on Economic Growth of Nigeria Disaggregated Approach. International Journal of Economics and Management Science 5: 369. DOI: 10.4172/2162-6359.1000369.

24. Ihugba, O. A. Chinedu, N. \& Njoku A.C (2013) An assessment of Nigeria expenditure on the agricultural sector: Its relationship with agricultural output. Journal of Economics and International Finance, 5(5), 177-186, DOI: 10.5897/JEIF2012.0471.

25. Ijaiya, M. A. \& Ijaiya, G.T. (2003). The Impact of Agricultural Finance on Agricultural Output in Nigeria. Poverty, Globalization and Human 186J. Econ. Int. Finance Development. Jugae, V.B (ed). www.unitlorin. edu.ng/ index. php/ijaiyama

26. Mapfumo, A., Mushunje, A., Chidoko, C. (2012) The impact of government agricultural expenditure on Economic growth in Zimbabwe. Journal of Economics and Sustainable Development, $3(10), 19-28$.

27. Muftau, A. I. \& Gafar, T. I. (2003). The Impact of Agricultural Finance on agricultural output in Nigeria. New Delhi; Serials Publications; 2003.

28. Okolo, D. A. (2004). "Regional Study on Agricultural Support: Nigeria's Case," being Special Study Report prepared for Food and Agricultural Organization (FAO).

29. Oriola, E.O. (2009). A framework for Food Security and Poverty Reduction in Nigeria. European Journal of Social Science. 8(1), 132 139.

30. Udoh, E. (2011) An examination of Public Expenditure, Private investment and Agricultural Sector Growth in Nigeria: Bounds Testing Approach. International Journal of Business and Social Science, 2(13), 285 - 292. 